\title{
Intangible Capital and Leverage*
}

\author{
Philipp Horsch $^{\mathrm{a}}$, Philip Longoni ${ }^{\mathrm{b}}$, David Oesch ${ }^{\mathrm{c}}$
}

September 19, 2019

\begin{abstract}
We investigate the causal effect of intangible capital on leverage. To address endogeneity, we exploit patent invalidations by the US Court of Appeals for the Federal Circuit, where judges are randomly assigned to cases. Differences in judge leniency provide exogenous variation in the probability that firms' patents are invalidated. Using this probability as an instrument for exogenous losses in intangible capital, we find a patent invalidation leads to a $14.1 \%$ reduction in leverage, suggesting that intangible capital causally supports leverage. This local average treatment effect is stronger in firms that use patents as loan collateral, in less creditworthy as well as in smaller firms. The deleveraging after patent invalidation is mainly driven by firms reducing short-term debt.
\end{abstract}

JEL Classification: G32, G33, O34

Keywords: $\quad$ Intangible Capital, Leverage, Capital Structure, Instrumental Variable

\footnotetext{
${ }^{*}$ We thank Andrea Bafundi, Constantin Charles, Jenny Chu, Ettore Croci (discussant), Günther Franke, Jasmin Gider, Xavier Giroud, María Gutiérrez Urtiaga, Michel Habib, Luzi Hail, Jens Jackwerth, Axel Kind, Anja Kunzmann (discussant), Christian Leuz, Paulo Maduro, Alberto Manconi, Evita Paraskevopoulou, Stephen Penman, Gaétan de Rassenfosse, Pablo Ruiz Verdú, Zacharias Sautner, Markus Schmid, Anna Toldrà Simats, Josep Tribó, Felix Urban, Alexander Wagner; seminar participants at Carlos III University of Madrid (UC3M), the University of Konstanz and the University of Zurich and conference participants at the 2018 FMA European Conference and at the 2017 Annual Conference of the Swiss Society for Financial Market Research for helpful discussions and valuable comments. This paper is part of Philip Longoni's doctoral dissertation at the University of Zurich.

${ }^{\text {a }}$ Parts of this paper were written while P. Horsch was at the University of St. Gallen and a visiting PhD student at New York University. He is now with a global management consulting firm. He thankfully acknowledges financial support from the Swiss National Science Foundation.

b Parts of this paper were written while P. Longoni was a visiting PhD student at Columbia University. He thankfully acknowledges financial support from the Swiss National Science Foundation.

${ }^{\mathrm{c}}$ Corresponding Author. University of Zurich, Department of Business Administration, Phoenixweg 5, 8032 Zurich, Switzerland. E-mail address: david.oesch@business.uzh.ch.
} 


\section{Introduction}

US businesses have more than doubled their investment in intangible capital since the end of World War II and, according to one estimate, invested 1.6 trillion USD, or $11.3 \%$ of GDP, in intangible capital in 2007 (Corrado and Hulten, 2010). In 2016, investments in intangible capital amounted to $14 \%$ of private sector GDP, while the corresponding rate for tangible capital was only 10\% (Wall Street Journal, 2016). Despite the increasing relevance of intangible capital, it is unclear whether and how these investments affect firms' financial policies, because our current understanding of the link between asset tangibility and leverage is incomplete (Graham, Leary, and Roberts, 2015). ${ }^{1}$

We use an instrumental variable research design to study how firms adjust leverage in reaction to negative exogenous shocks to their intangible capital. We estimate the causal effect of intangible capital on leverage from a hand-collected sample of publicly listed firms that experience 579 patent invalidity decisions at the US Court of Appeals for the Federal Circuit between 1983 and 2014. We find that, when a firm's patent is invalidated by the court, book leverage decreases by 14.1 percentage points over the next year. Our finding thus suggests the existence of a substantial, positive, and causal effect of intangible capital on leverage. The result is robust to changes in the definition of leverage and in the model specification.

In more granular capital structure regressions, we seek to better understand how the deleveraging after patent invalidations materializes. We base our tests on recent work on corporate deleveraging (DeAngelo, Gonçalves, and Stulz, 2018; Dangl and Zechner, 2018) by separately examining the effect of patent invalidations on short-term and long-term debt,

\footnotetext{
${ }^{1}$ As Graham et al. (2015: 669-670) point out: "Asset tangibility, despite large fluctuations in the 1940s and 1950s, generally declined over the century. Not only does this pattern miss some of the important turning points in leverage, it is also difficult to reconcile with existing empirical evidence (e.g., Frank and Goyal, 2009) and theory (e.g., Shleifer and Vishny, 1992), which suggests that decreasing asset tangibility decreases debt capacity because there is less collateral to secure debt."
} 
earnings retention and equity issuance. We find that reductions in short-term debt are the main driver behind the deleveraging we document.

Our instrumental variable identification strategy specifically addresses the potential endogeneity in the relationship between intangible capital and leverage. Endogeneity may be caused by omitted unobservable variables, reverse causality or measurement error. An unobservable variable (such as managerial risk aversion) affecting a firm's choice of intangible capital could potentially also affect a firm's choice of leverage, thereby challenging a causal interpretation of an empirically documented correlation between intangible capital and leverage. In addition to correlated unobservable variables across firms, causal inference is also troubled by a potential reverse effect of leverage on intangible capital. For instance, firms might raise debt to purchase intangible assets. Lastly, book values of intangible capital are prone to measurement error because firms' balance sheets do not appropriately reflect intangible capital under current accounting rules (Barth, Kasznik, and McNichols, 2001; Corrado and Hulten, 2010; Myers, 1984). These factors may lead to biased and inconsistent estimates when endogeneity is not addressed while studying the link between intangible capital and leverage. In fact, when we run naïve ordinary least squares (OLS) regressions of leverage on patent invalidation, we find no statistically significant effect, highlighting the importance of accounting for endogeneity in our setting.

The identification strategy in our paper follows Galasso and Schankerman (2015) and exploits the institutional characteristics of the US Court of Appeals for the Federal Circuit, which is the only appellate court for patent litigation in the US. A possible outcome of court cases at the Federal Circuit is the invalidation of a firm's patent. If the Federal Circuit invalidates a firm's patent, the firm loses intangible capital, namely the right to bar others from producing, using, or selling the firm's invention throughout the US, or from importing the invention to the US (35 US Code $§ 271$ ). 
It is "a fortunate institutional fact" (Galasso and Schankerman, 2015: 320) that, for each court case reaching the Federal Circuit, a computer program randomly draws three out of the 12 available judges which make up the court, and assigns them to a court case. Whether a threejudge panel will invalidate a firm's patent can be predicted, because each judge's attitude towards patent validity is known. These two institutional idiosyncrasies - random assignment of judges to court cases and systematic, observable differences in judge leniency - allow us to construct an instrument that provides us with plausibly exogenous variation in patent invalidations, which we use as a proxy for plausibly exogenous decreases in firms' intangible capital. The instrument that we use is the likelihood that the three judges randomly assigned to a court case invalidate a firm's patent.

The main innovation of our paper is to document a causal positive effect of firms' intangible capital on leverage. While previous studies present evidence consistent with the hypothesis that more intangible capital may lead to higher leverage (e.g., Larkin, 2013; Lim, Macias, and Moeller, 2018), they carefully state that a causal interpretation is complicated by the likely presence of correlated unobservable variables. Our study allows us to isolate the causal effect of intangible capital on leverage, because our instrumental variable research design introduces plausibly exogenous negative shocks to firms' intangible capital.

Our study also contributes to a better understanding of the puzzling finding that leverage has generally increased over the past century, while asset tangibility has decreased (Graham et al., 2015), which could seem at odds with previous literature that suggests a positive correlation between asset tangibility and leverage (e.g., Frank and Goyal, 2009; Harris and Raviv, 1991; Graham and Leary, 2011; Leary and Roberts, 2014; Lemmon, Roberts, and Zender, 2008; Rajan and Zingales, 1995; Shleifer and Vishny, 1992; Titman and Wessels, 1988). Our findings indicate that the historical growth in firms' intangible capital over the past decades (e.g., 
Corrado and Hulten, 2010) could be an important factor in explaining growth in leverage over time.

Further, we extend the relatively new and growing field of research that studies the effect of patents on corporate financial outcomes. Chava, Nanda, and Xiao (2017) document that increases in patent protection and creditor rights over collateral result in cheaper bank loans, possibly because lenders value innovative activity. Farre-Mensa, Hegde, and Ljungqvist (forthcoming) find that, for start-up firms, the first patent approval increases the likelihood of securing funding from professional investors by $47 \%$ over the next three years. Taken together, this literature suggests that patents may facilitate firms' access to both debt and equity financing. Our study complements these findings by showing that, among publicly listed companies, intangible capital shapes capital structure by acting as a leverage-supporting device. Our heterogeneous treatment results are consistent with Mann's (2018) finding that the practice of using patents as collateral, where firms pledge patents as collateral under a loan agreement, may increase firms' debt capacity. In addition, our findings suggest that intangible capital might positively affect debt capacity even when intangible capital is not formally pledged as collateral.

\section{Identification Strategy: Instrumental Variable Based on Patent Invalidations}

\subsection{Identification Strategy: Background}

Our paper applies an instrumental variable identification strategy introduced by Galasso and Schankerman (2015) to overcome the endogeneity and measurement issues described above. We use court judgments in which a court invalidates a firm's patent (patent invalidity decisions) as a source of negative shocks to firms' intangible capital and examine how firms adjust leverage in reaction to such shocks. To be able to address the potentially endogenous nature of patent invalidity decisions, we require an instrumental variable that is related to the patent invalidation likelihood but not related to our outcome variable of interest (i.e., leverage). 
We exploit the method by which judges are assigned to court cases at the Federal Circuit for the construction of our instrument. At the Federal Circuit, a computer program randomly draws three out of the 12 judges making up the Federal Circuit and assigns the three judges to a case. ${ }^{2}$ The three-judge panel then decides by majority vote whether a patent is invalid. Our identification strategy also exploits the fact that a judge's history of invalidity decisions is correlated with the likelihood of her being in favor of patent invalidation. Taken together, these two aspects of our research setting provide us with exogenous variation in patent invalidity decisions.

We compute our instrumental variable, judges' invalidation propensity $(J I P)$, per patent invalidity decision $p$ as

$$
J I P_{p}=f_{p}^{1} f_{p}^{2} f_{p}^{3}+f_{p}^{1} f_{p}^{2}\left(1-f_{p}^{3}\right)+f_{p}^{1}\left(1-f_{p}^{2}\right) f_{p}^{3}+\left(1-f_{p}^{1}\right) f_{p}^{2} f_{p}^{3},
$$

where the variables $f_{p}^{1}, f_{p}^{2}$ and $f_{p}^{3}$ are the individual patent invalidation rates of the three judges randomly assigned to the panel. For any judge $X, f_{p}^{X}$ is the fraction of votes in favor of patent invalidity over her entire Federal Circuit career. ${ }^{3} J I P_{p}$ is thus the weighted probability that the randomly assigned three-judge panel invalidates a patent. It is based on all four scenarios that could lead to patent invalidation (one unanimous vote for invalidity, and three two-to-one votes for invalidity). For instance, the term $f_{p}^{1} f_{p}^{2}\left(1-f_{p}^{3}\right)$ captures the probability that judges one and two vote for invalidation, while judge three votes against it. Appendix A provides a list of judges and their individual patent invalidation propensities $\left(f_{p}^{X}\right)$.

As Galasso and Schankerman (2015) argue, JIP's validity as an instrument is founded on two characteristics. First, the random assignment of judges to court cases ensures that there

\footnotetext{
${ }^{2}$ One caveat to our identification strategy is its reliance on the random assignment of judges to cases. Hall (2010) and Chilton and Levy (2015) investigate and question the extent of randomness in the assignment of judges to cases (in their case at the US circuit courts).

${ }^{3}$ We follow Galasso and Schankerman (2015) and exclude the patent invalidity decision $p$ itself from the computation of $f_{p}^{X}$ to ensure that the patent invalidity decision $p$ does not affect its own instrument.
} 
is no systematic assignment of judges with a particular invalidation propensity to cases with unobservable characteristics that could be correlated with leverage. Second, because we exclude the invalidity decision $p$ when computing $J I P$ for invalidity decision $p$, we are able to remove case-specific unobservable factors potentially affecting invalidity decision $p$.

The assumption that a patent invalidation represents a meaningful negative shock to firms' intangible capital is well supported by the institutional setting: Since the Federal Circuit is an appellate court, both litigants are likely to have discarded alternative settlement options, such as out-of-court settlement or settlement after the first instance's decision. The choice to continue costly litigation at the Federal Circuit indicates that both litigants consider the focal patent valuable.

Table 1 provides descriptive evidence indicating that sample patents are indeed highly valuable, both scientifically and economically. In Panel A, we examine whether sample patents are cited more frequently than other US patents. We obtain patent citation data from the NBER Patent Data Project and truncation-adjust that data using the adjustment factor by Hall, Jaffe and Trajtenberg (2001). Patent citation data is available for 401 sample patents and 3,208,645 other US patents issued between 1976 and 2006. We find that mean Citations received is 49.8 for sample patents and 11.8 for other US patents. The difference in means is statistically significant ( $p$-value $<0.01)$, indicating that sample patents are cited more often, possibly because they represent more valuable scientific capital. This finding is confirmed when we compare citations received on a per-claim basis. Our results support the conclusion of Galasso and Schankerman (2015), who (based on findings which we reproduce in Table 1) state that "patents involved in Federal Circuit cases are a selected sample of highly valuable patents" (p. 331).

In Panel B, we use the stock market-based measure of economic patent value by Kogan, Papanikolaou, Seru, and Stoffman (2017), which is available for 256 sample patents and $1,790,342$ other US patents. We find that when a sample patent is granted to a firm, firm value 
increases on average by 17.6 million USD in the three-day window around the grant date, or by 28.6 million USD when expressed in 2017 USD. In contrast, when a non-sample patent is granted, the mean firm value increase is 10.4 million USD (or 22.4 million, expressed in 2017 USD). The difference in means is statistically significant for both the nominal measure ( $p$-value $<0.01)$ and the inflation-adjusted measure $(p$-value $<0.1)$. These results suggest that sample patents are of above-average economic value.

\subsection{Identification Strategy: Empirical Implementation}

We implement the identification strategy as follows: We hand-collect a sample of firmpatent invalidity decisions in which each observation represents a decision by the Federal Circuit on the invalidity of a patent owned by a firm. We define a patent invalidation dummy, Invalidated $_{i, p}$, as one if the patent invalidity decision $p$ invalidates a patent owned by firm $i$, and zero if the patent is not invalidated. We follow Angrist and Pischke (2009) and Wooldridge (2010) and account for the binary nature of the instrumented endogenous variable by instrumenting Invalidated $_{i, p}$ with the predicted invalidation probability obtained from the probit model

$$
\hat{P}_{i, p}=P\left(J I P_{i, p}, X_{i, p}\right),
$$

where $J I P_{i, p}$ is the panel's invalidation propensity (defined in Equation (1)), and $X_{i, p}$ is a vector of control variables including industry indicators, year indicators, and a set of lagged firm-level control variables. We then implement our instrumental variable research design by estimating the following two-stage model with a two-stage least squares (2SLS) estimate. Equation (3) denotes the first stage; Equation (4) denotes the second stage:

$$
\begin{gathered}
\text { Invalidated }_{i, p}=\alpha \widehat{P}_{i, p}+\delta^{\prime} X_{i, p}+u_{i, p}, \\
\text { Leverage }_{i, p}=\beta \text { Invalldated }_{i, p}+\gamma^{\prime} X_{i, p}+\varepsilon_{i, p} .
\end{gathered}
$$

Equation (3) is an OLS regression of Invalidated $_{i, p}$, the patent invalidation dummy, on $\hat{P}_{i, p}$, the patent invalidation propensity predicted from the probit model shown in Equation (2). 
From this first-stage regression, we predict Invalldated ${ }_{i, p}$ (i.e., instrumented patent invalidation), which we use as an independent variable in the second-stage regression (Equation (4)). We measure leverage, the dependent variable, in the period following the patent invalidity decision because we study whether and how firms adjust their leverage in the wake of a patent invalidation. The coefficient $\beta$ in Equation (4) captures the causal effect of a loss of intangible capital on leverage. A negative estimate of $\beta$ indicates that a loss of intangible capital leads to a reduction in leverage.

The vector of control variables $X_{i, p}$ is the same for all main regressions. We control for financial variables that prior empirical research has identified as significant predictors of leverage, such as firm size, market-to-book ratio, profitability and asset tangibility (e.g., Frank and Goyal, 2009; Leary and Roberts, 2014; Rajan and Zingales, 1995). We measure these firmlevel controls at the end of the last fiscal year preceding the fiscal year of the patent invalidity decision to ensure that they are not affected by the decision. We also include lagged leverage to control for serial correlation in leverage, following Lemmon et al. (2008, p. 1577). ${ }^{4}$ In addition, we include industry fixed effects based on the Fama and French 48 industry classification and decision-year fixed effects. Since some companies experience multiple patent invalidity decisions, we cluster standard errors at the firm level in all regressions.

\section{Data and Sample}

\subsection{Patent Invalidity Decisions}

We search the LexisNexis Federal Court Cases database for all court opinions published between 1982 (the year the Federal Circuit was established) and 2015 that contain the keywords "Court of Appeals for the Federal Circuit", "patent or patents" and "invalid or invalidity or unenforceable". Of the resulting 3,201 court opinions, we drop those for which at least one of

\footnotetext{
${ }^{4}$ In unreported robustness tests, we additionally control for industry-year median and mean leverage, the modified Altman (1968) Z-Score, firm age, a dividend payer dummy, the term spread, and the credit spread. This does not significantly affect our main result.
} 
the following criteria applies: 1) the Federal Circuit does not explicitly reconsider the lower court's decision regarding patent invalidity, 2) the judge panel does not consist of three judges, 3) the patent invalidity decision is unclear, for instance, if the Federal Circuit sends the case back to the lower court without instructions regarding patent invalidity.

We compile a list of all patent invalidity decisions contained in the remaining 1,284 court opinions. For every patent invalidity decision, we record the following information: the names of the three Federal Circuit judges on the panel, the publication date of the court opinion, the name of the company asserting patent validity, the patent number and whether the Federal Circuit invalidates the patent. Following Galasso and Schankerman (2015), we consider a patent invalidity decision as a patent invalidation if it invalidates at least one patent claim.

\subsection{Matching Patent Invalidity Decisions with Firm Financials}

We merge our dataset of patent invalidity decisions with firm financials by manually matching the names of the legal entities asserting patent validity with the backfilled variable conm from the Annual Compustat North America database. For invalidity decisions that we could not match to Compustat via the conm variable, we perform online searches of the legal entities asserting patent validity. If a newer company name of the legal entity exists in Compustat, we assign the invalidity decision to the respective firm's Compustat entry. If we find that a legal entity in the court opinion is a subsidiary of a firm covered by Compustat, we assign the invalidity decision to the parent company's Compustat entry. Following the empirical capital structure literature, we exclude banks, insurance companies, and regulated utility firms from our sample by dropping observations with four-digit SIC (sich) codes between 4000 and 4999 and between 6000 and 6999.

For each matched invalidity decision, we add the financial information reported in the three-year window around the year in which the court decision was published $[-1 ;+1]$. We use the firm financials from year $t+1$ to compute the dependent variable, a measure of leverage, at 
the end of the first fiscal year after the invalidity decision. We require firm financials from fiscal year $t-1$ to compute the lagged firm-level control variables. This one-year lag ensures that the control variables are not affected by the court decision because the court decision is not yet known at the time when control variables are measured. To reduce the impact of outliers on our estimates, we winsorize all financial ratios at the 1st and 99th percentiles of their distributions.

\subsection{Sample}

Our final sample contains 579 patent invalidity decisions. They result from 347 Federal Circuit court cases held between 1983 and $2014 .{ }^{5}$ The invalidity decisions affirm or remove the validity of 518 unique patents (some patents are disputed more than once before the Federal Circuit). Overall, 205 distinct firms are affected by the invalidity decisions in our sample. The firms are mainly from the pharmaceutical, electronic equipment, medical equipment and chemicals industries, which together account for $48 \%$ of sample firms. Firms in our sample experience 2.8 patent invalidity decisions on average.

Panel A of Table 2 reports descriptive statistics of the invalidity decision variables. The Federal Circuit invalidates a patent in $45 \%$ of observations, which is comparable to previous studies. For example, between 1982 and 1994, our rate is 34\%, compared to $33 \%$ found in Dunner, Jakes, and Karceski (1995). For the period from 1983 to 2008, 42\% of validity decisions in our sample are invalidations, compared to 39\% in Galasso and Schankerman (2015). JIP, the invalidation rate predicted from randomly assigned three-judge panels, is $42 \%$ on average and shows substantial variation, ranging from $10 \%$ to $74 \%$. Appendix B summarizes all variable definitions.

\footnotetext{
${ }^{5} \mathrm{We}$ lose the invalidity decisions of the years 1982 and 2015 because we require lagged and leading firm financials to estimate the coefficients of Equations (3) and (4).
} 


\subsection{Dependent Variables}

Panel B of Table 2 summarizes the dependent variables used throughout this study. We define book leverage, our main variable of interest, as total debt (long-term debt (Compustat item $d l t t)$ plus short-term debt $(d l c)$ ) divided by the book value of total assets $(a t)$, following Leary and Roberts (2014).

We compute additional leverage variables for robustness tests: Following Leary and Roberts (2014), market leverage is total debt divided by the market value of assets (MVA), where MVA equals the sum of the market value of equity (common shares outstanding (cshpri) multiplied by the stock price at the end of the fiscal year ( $\left.\operatorname{rrc} \_f\right)$ ), total debt and the liquidating value of preferred stock ( $p s t k l)$, minus deferred tax credits (txditc). We calculate lease-adjusted book leverage following Rampini and Viswanathan (2013) by adding 10 times the value of outstanding rental expenses to both the numerator and the denominator of book leverage. Following Serfling (2016), we compute net book leverage as total debt minus cash and shortterm investments (che) divided by total book assets. We define firms as net debt issuers if net debt issuance is above $1 \%$, where net debt issuance is the first difference in total debt divided by lagged total assets (as in Leary and Roberts, 2014).

For our examination of debt channels which might affect leverage, we compute additional variables: Short-term leverage is short-term debt divided by total assets. We divide the change in short-term debt by lagged short-term debt to obtain the percentage change in short-term debt. As the distribution of the percentage change in short-term debt contains substantial outliers even after winsorizing, we also compute the change in short-term debt divided by lagged total assets, which results in a narrower distribution. In the same manner, we compute long-term leverage, the percentage change in long-term debt, and the change in longterm debt in percentage of lagged total assets. 
We also calculate variables to study equity channels which might affect leverage. The retained earnings-to-assets ratio is retained earnings (re) divided by total assets. We define retained earnings growth as the change in retained earnings divided by lagged total assets. We calculate the equity-to-assets-ratio as common equity (ceq) less retained earnings divided by total assets. Equity issuance is the percentage change in common equity minus retained earnings. As for changes in long-term debt and short-term debt, we also express the change in common equity (less retained earnings) as a percentage of lagged total assets.

\subsection{Further Variables}

Panel $\mathrm{C}$ of Table 2 summarizes control variables and variables used for tests of heterogeneous treatment effects. We follow Leary and Roberts (2014) for the computation of our set of firm-level control variables. The control variables are firm size (defined as the natural logarithm of net sales (sale)), market-to-book ratio (MVA divided by at), profitability (EBITDA (oibdp) divided by at) and tangibility (PP\&E (ppent) divided by $a t$ ).

We use patent collateral data from the US Patent and Trademark Office (USPTO) to compute additional variables required to test for heterogeneous treatment effects. For each patent in our final sample, we identify patent collateral by scanning the assignment history for the keywords "security", "collateral", "lien" and "mortgage", following Hochberg, Serrano and Ziedonis (2018). Using the assignment recording date, we create a dummy variable (Patent is collateral) that equals one if a patent was assigned to a lender as collateral under a security agreement at the time of the invalidity decision. Finally, we construct the modified Altman (1968) Z-Score as in Leary and Roberts (2014) as the sum (normalized by at) of 330\% of pretax income (pi), 100\% of sale, $140 \%$ of retained earnings (re) and $120 \%$ of working capital (current assets (act) minus current liabilities $(l c t))$. 


\section{Results}

\subsection{First-Stage Regression: Predicting Patent Invalidations}

In an instrumental variable research design, a valid instrument needs to meet the relevance and exclusion conditions (Wooldridge, 2010). The first-stage regression results show whether an instrument satisfies the relevance condition (Roberts and Whited, 2013). In Table 3 , we present the results from estimating three variants of the first-stage regression. Column (1) shows the results from the OLS regression of the invalidation dummy Invalidated (which equals one if a patent is invalidated) on $J I P$, year and industry fixed effects. We find that $J I P$ is a statistically strong predictor of the Federal Circuit's patent invalidity decision at the $1 \%$ significance level, with a $t$-value of 3.30. The Kleibergen-Paap (2006) F-statistic is 10.90, indicating that the partial correlation of JIP with Invalidated is sufficient for JIP to be considered a strong instrument (Staiger and Stock, 1997; Stock and Yogo, 2005).

In Column (2), we replace $J I P$ with the invalidation probability predicted from a probit regression of the invalidation dummy Invalidated on JIP and controls. Since the invalidity decision is a binary endogenous variable, this estimator is more efficient (Wooldridge, 2010), and thus, as expected, the F-statistic increases to $14.82 .{ }^{6}$ In Column (3), we add firm-level control variables to the first-stage regression. While none of the firm-level variables correlates with the Federal Circuit decision, JIP continues to reliably predict the court decision, with an F-statistic of 14.14. Our first-stage regression estimates show that JIP meets the relevance condition required for a valid instrument.

The exclusion restriction requires the correlation between the error term and the instrument to be zero (Wooldridge, 2010). In the context of this paper, the exclusion restriction is fulfilled if the instrument $J I P$ affects a firm's leverage ratio exclusively through the influence

\footnotetext{
${ }^{6}$ Our results are confirmed when we directly use $J I P$ as the instrumental variable.
} 
$J I P$ has on the patent invalidity decision (Invalidated, i.e., the endogenous independent variable). Whether the exclusion restriction is met cannot be formally tested because the error term is unobservable (Angrist and Pischke, 2009). In our setting, however, the random assignment of judges to court cases by a computer program supports the idea that the exclusion restriction is met. As our instrument $J I P$ is computed from three randomly assigned variables $\left(f_{p}^{X}\right)$, it is likely to be uncorrelated with variables other than the patent invalidity decision.

\subsection{Second-Stage Regression: The Effect of Intangible Capital on Leverage}

Panel A of Table 4 presents the main results of our empirical investigation of the effect of intangible capital on leverage. As a benchmark, we first present the results of simple OLS regressions that correlate leverage with the endogenous patent invalidity decision. In Column (1), we present the result from regressing book leverage in the year after the court decision on Invalidated, year and industry fixed effects. The coefficient of patent invalidation is small (0.005) and not statistically significant, suggesting no significant correlation between patent invalidation and leverage. This result is affirmed if we account for observable differences in determinants of leverage across firms in Column (2).

To address endogeneity and move towards a causal estimate of the effect of intangible capital on leverage, we next apply the instrumental variable research design described in Section 1. The results from the second-stage regression shown in Column (3) reveal a negative and statistically significant relationship between instrumented patent invalidation and leverage. Column (4) shows that even after controlling for observable firm-level determinants of leverage, industry and year fixed effects, an exogenous decrease in intangible capital, proxied for by the invalidation of a patent, leads firms to reduce leverage. The estimated coefficient of -0.141 is also economically meaningful, as it indicates that a patent invalidation leads to a leverage reduction of 14.1 percentage points over the next year (about one sample standard deviation). 
It is important to note that the 2SLS estimate in Column (4) documents a local average treatment effect (LATE, see Imbens and Angrist, 1994) and is thus difficult to generalize. This LATE only reflects the effect of patent invalidation on leverage for firms who would not have experienced patent invalidation had they been assigned to different judges. Our results do not capture the effect of intangible capital on leverage for firms whose patents would always or never be invalidated, regardless of the leniency of the randomly assigned judge panel. ${ }^{7}$

Given the specific setting of our study, the identified treatment effect is highly local, and the external validity of our results is likely limited (see e.g., Angrist and Pischke, 2009). The effect of intangible capital on leverage we document is valid among firms who own at least one valuable patent, who choose to engage in costly litigation at the appellate court to defend their patent (maybe because it is their most valuable asset), and who keep or lose their patent solely due to the level of strictness of the randomly assigned judge panel. Due to the substantial costs associated with such litigation and the high value of the patents litigated, it is reasonable to assume that the effect of patent invalidation will be relatively large in our setting.

Our main finding of a reduction in intangible capital leading to lower leverage suggests that intangible capital supports leverage. The literature has so far concluded that tangible assets, not intangible assets, support leverage (e.g., Frank and Goyal, 2009; Titman and Wessels, 1988). Tangible capital is believed to decrease expected distress costs (Lemmon and Zender, 2010) because it contains low information asymmetry, which reduces debt-related agency problems (Long and Malitz, 1985), and because it is easier to value, thereby adding to liquidation value (Harris and Raviv, 1991; Zou and Adams, 2008). However, as we noted in the Introduction, Graham et al. (2015) point out that asset tangibility has generally decreased over the past decades while leverage ratios have increased.

\footnotetext{
7 The treatment effects literature refers to those firms as "always-takers" and "never-takers" of treatment, respectively (e.g., Atanasov and Black, 2016).
} 
Our result presents one possible explanation for the incomplete tangibility-leverage relationship: Intangible capital seems to be an important support of leverage, which might explain the positive correlation between intangible capital and leverage presented by other studies (e.g., Larkin, 2013; Lim et al., 2018). Note that some earlier studies use book intangible assets divided by total book assets as a proxy for asset intangibility (e.g., Titman and Wessels, 1988). Given that intangible assets are normally unrecognized in balance sheets (Barth et al., 2001), any estimate obtained from a regression of leverage on a measure containing book intangible assets is likely biased and inconsistent. The lack of an obvious measure for intangible capital creates a degree of freedom that allows our finding to complement rather than contradict previous studies. While firms with a high fraction of tangible capital in their balance sheet may exhibit higher leverage, our study suggests that intangible capital causally supports leverage.

\subsection{Robustness Tests}

We next present the results from robustness tests to demonstrate that our main result shown in Column (4) of Panel A of Table 4 is not particular to the specific leverage measure or the specific empirical specification we use.

In Panel B of Table 4, we present 2SLS estimates of the effect of a loss in intangible capital, proxied for by patent invalidations, on several alternative leverage measures. In Column (1), we use market leverage instead of book leverage. While book leverage is more relevant for managers when making capital structure decisions (Graham and Harvey, 2002) and is a cleaner measure of debt policy (Heider and Ljungqvist, 2015), market leverage is more relevant for theoretical predictions related to target leverage ratios (Serfling, 2016). We find that the effect of patent invalidation on market leverage is significant and nearly identical to book leverage.

In Column (2), the dependent variable is lease-adjusted book leverage. Not accounting for operating leases may result in the underestimation of a firm's true magnitude of leverage (Eisfeldt and Rampini, 2009; Rampini and Viswanathan, 2013; Rauh and Sufi, 2012). We find 
that using lease-adjusted leverage does not change the inferences from our main result. In Column (3), we use net book leverage as the dependent variable. Our main finding of a significantly negative effect of a loss of intangible capital on leverage is again confirmed when we use this measure. In Column (4), we use the net debt issuer dummy as the dependent variable. We find that net debt issuance decreases significantly after a patent invalidation. Thus, all alternative leverage measures confirm our main result that intangible capital affects leverage.

In Panel $\mathrm{C}$ of Table 4, we document that our main finding is robust to changes to our empirical implementation of the instrumental variable research design. First, we test whether our result depends on measuring firm-level control variables at $t-1$. One could worry that other developments occurring between $t-1$ and $t+1$ (when the dependent variable is measured) could contribute to the effect we document. We thus reduce the lag between the control variables and the outcome variable by shifting the control variables closer to the invalidity decision. In Column (1), we present the results of measuring control variables at $t=0$, i.e., in the year of the court decision. We again find that patent invalidation leads to lower leverage. Unreported results also show that measuring the control variables in the year after the invalidity decision does not critically affect our main result.

We vary our choice of outlier treatment and winsorize the top and bottom $5 \%$ of all financial variables instead of the top and bottom $1 \%$ in Column (2). This different outlier treatment does not substantially change our results, and we continue to find a significantly negative effect of instrumented patent invalidation on leverage. The same holds if we do not winsorize our data at all or if we winsorize at the top and bottom $10 \%$ (not reported).

In Column (3), we run a regression of changes in leverage on changes in control variables (following e.g., Heider and Ljungqvist, 2015; Leary and Roberts, 2014), to address concerns over potential omitted firm-level characteristics. The dependent variable is the oneyear change in the book leverage ratio, computed as the first difference between year $t=0$ and 
year $t+1$. The control variables are the first differences measured between year $t-2$ and year $t$ 1. The estimated coefficient $(-0.069, t$-value of -2.24$)$ suggests a significant negative effect of patent invalidation on the change in leverage, which implies that unobserved firm-specific variables do not unduly influence our results.

As a last robustness check, we modify the unit of observation of our analysis. For this test, we collapse our sample from the firm-invalidity decision level used in the analyses presented so far to the firm-case level. Sample size decreases because some Federal Circuit court opinions present multiple patent invalidity decisions (i.e., the court opinions contain invalidity decisions for several patents). We define case-level $J I P$ as the mean $J I P$ per case and set the invalidation dummy to one if at least one patent is invalidated during the case. In Column (4), we show that we still find a significantly negative effect of patent invalidation on leverage when using this alternative unit of observation.

\section{Heterogeneous Effects of Intangible Capital on Leverage}

Table 5 presents the results from our tests of heterogeneous treatment effects. We study whether the treatment effect depends on firms' use of patent collateral, distance-to-default and size. $^{8}$

Prior research shows that firms increasingly use patents as collateral to obtain credit financing (Loumioti, 2013; Mann, 2018). Following Hochberg et al. (2018), and as described in Section 2.5, we identify 45 firm-invalidity decisions in which a patent was pledged as collateral under a lending agreement at the time of the patent invalidity decision. Patent is Collateral equals one for these observations, and zero for all others. The results presented in Column (1) of Table 5 reveal a negative and statistically significant (at the $10 \%$ level)

\footnotetext{
${ }^{8}$ In unreported results, we also test whether firms' patent invalidation history could impact the effect uncovered so far. We find that the effect of an additional patent invalidation on leverage is smaller (albeit not statistically significantly so) compared to a first-time patent invalidation.
} 
coefficient of -0.284 on the interaction term Invalidation $\times$ Patent is Collateral. This estimate indicates that firms reduce leverage significantly more after losing a patent that serves as loan collateral (compared to firms losing a patent that is not used as collateral). The coefficient on instrumented invalidation (-0.106), which in this regression captures the causal effect of patent invalidation on leverage when patents are not collateral, is also negative and significant, suggesting that the collateral channel is not the only driver behind our main finding.

Next, we investigate whether the debt-supporting role of intangible capital is more pronounced for borrowers closer to default. Possibly, these firms have exhausted most or all of their debt capacity and thus a sudden loss in intangible capital might disproportionately affect their capital structure. We proxy for creditworthiness with a firm's distance-to-default measured by the modified Z-Score. ${ }^{9}$ We split our sample using the median Z-Score measured at the end of the fiscal year prior to the invalidity decision to ensure that the outcome of the invalidity decision does not affect the sample split. In Column (2), we find a statistically significant coefficient on the interaction term (Invalidation $\times$ Low Z-Score) of -0.151 . This estimate indicates that firms closer to default reduce leverage significantly more after experiencing a patent invalidation (compared to firms with higher Z-scores). For firms with a higher distanceto-default, the insignificant coefficient of -0.062 on instrumented invalidation suggests a comparatively weaker leverage-supporting role of intangible capital.

Finally, we also investigate whether the effect of patent invalidation on leverage varies with firm size. Column (3) presents the results. We again split the sample, this time using the median size measured at the end of the fiscal year prior to the invalidity decision. The estimated coefficient on the interaction term (Invalidation $\times$ Small Firm) is negative $(-0.148)$ and statistically significant at the $10 \%$ level. This finding shows that smaller firms suffer significantly more from a loss of intangible capital than larger firms, possibly because they

\footnotetext{
${ }^{9}$ Our inferences remain unchanged if we instead use interest coverage as a proxy for creditworthiness.
} 
could find it harder to convey information related to this event to capital providers. While capital providers of larger firms have access to a wealth of information about these firms, there is considerably less information available for smaller firms.

\section{How Does the Deleveraging After Patent Invalidation Materialize?}

In this final section, we investigate the channel through which our main result (the leverage reduction following patent invalidation) takes effect. To this end, we document the results of two sets of additional and more granular capital structure regressions, which are based on arguments from recent research on corporate deleveraging (Dangl and Zechner, 2018; DeAngelo et al., 2018). ${ }^{10}$ Table 6 presents the results. In Panel A, we show how patent invalidations could drive deleveraging through the debt channel, i.e., by motivating firms to reduce short-term and/or long-term debt. In Panel B, we show how patent invalidations might affect deleveraging via the equity channel, i.e., by leading firms to increase retained earnings and/or to issue new equity (Panel B). ${ }^{11}$

In Column (1) of Panel A, we test whether patent invalidations affect firms' short-term leverage. The second-stage regression yields a coefficient of -0.052 on instrumented patent invalidation (statistically significant at the 5\% level), indicating that firms reduce short-term leverage after a patent invalidation. This estimated coefficient is also economically significant, as it indicates that a patent invalidation leads to a reduction of short-term leverage of 5.2 percentage points (about one sample standard deviation). As the dependent variable is a ratio, a reduction could be explained by a patent invalidation causing a decrease in the numerator (i.e., in short-term debt), and/or an increase in the denominator (i.e., in total assets), hence, it

\footnotetext{
${ }^{10}$ DeAngelo et al. (2018) study firms deleveraging from historical leverage peaks and find that debt repayment (which reduces both the leverage ratio's numerator and denominator), earnings retention, and equity issuance (which both increase the leverage ratio's denominator) drive deleveraging, with debt repayment being the strongest deleveraging channel. Dangl and Zechner (2018) show that debt maturity may affect deleveraging.

${ }^{11}$ The loss of observations in Columns (2) and (5) of Panel A is mainly caused by firms exhibiting zero short- or long-term debt, respectively, in the year of or before the patent invalidity decision.
} 
would be premature to conclude from this finding that firms reduce short-term debt after losing intangible capital. ${ }^{12}$

To learn whether firms in fact reduce short-term debt following a patent invalidation, we use the percentage change in short-term debt, which is unaffected by changes in total assets, as the dependent variable in Column (2). The 2SLS regression estimates a coefficient of -7.193 for instrumented patent invalidation. While this coefficient is statistically significant at the $5 \%$ level, its size indicates that it may be inflated by outliers in the distribution of the dependent variable. To obtain a less distorted estimate of the impact of patent invalidations on short-term debt, in Column (3) we express the change in short-term debt as a fraction of lagged total assets. ${ }^{13}$ We lag total assets by one year to ensure they are not yet affected by the outcome of the patent invalidity decision. The statistically significant negative coefficient of -0.053 , combined with the result of Column (2), suggests that reductions in short-term debt are meaningful drivers of the documented reduction in short-term leverage.

We next analyze how patent invalidations affect long-term leverage and long-term debt. In Column (4), the dependent variable is long-term leverage. The estimated coefficient (-0.090, $t$-value of -1.75) suggests that a patent invalidation leads to significantly lower long-term leverage. As noted above, the negative coefficient could indicate that patent invalidations trigger a reduction in long-term debt and/or an increase in long-term leverage's denominator. To clarify whether long-term debt reductions may drive the deleveraging after patent invalidations, we next show how patent invalidations affect the percentage change in long-term debt in Column (5). We obtain a negative and statistically insignificant coefficient on

\footnotetext{
${ }^{12}$ Speaking to this point, DeAngelo et al. (2018) show that around $18 \%$ of firms even increase debt while deleveraging.

${ }^{13}$ This alternative definition provides two benefits, compared to the percentage change in short-term debt used in Column (2). First, dividing by lagged total assets reduces the range of the distribution of the dependent variable. Second, this definition allows us to compute short-term debt changes for firms that reported zero short-term debt in the year of the patent invalidity decision.
} 
instrumented invalidation $(-0.126, t$-value of -0.31$)$. The insignificant effect of patent invalidations on long-term debt is confirmed in Column (6), where the change in long-term debt is divided by lagged total assets (in the spirit of Column (3) for short-term debt). The estimated coefficient on instrumented invalidation $(-0.042)$ is statistically insignificant with a $t$-value of 0.65. The mixed evidence presented in Columns (4) to (6) indicates that firms seem to primarily deleverage by reducing short-term debt.

In Panel B of Table 6, we present 2SLS estimates of the effect of patent invalidation on measures of earnings retention (Columns (1) and (2)) and equity issuance (Columns (3) to (5)). DeAngelo et al. (2018) find that both channels can contribute substantially to firms' deleveraging (albeit to a lesser degree than debt repayments).

We examine how a patent invalidation affects the ratio of retained earnings to total assets in Column (1). The 2SLS regression returns a coefficient of -0.207 on instrumented patent invalidation. The coefficient is statistically insignificant ( $t$-value of -0.52$)$, suggesting that a patent invalidation does not affect the ratio of retained earnings to total assets. In Column (2), the dependent variable is the change in retained earnings divided by lagged total assets. The coefficient on instrumented invalidation is positive (0.111) and statistically insignificant, indicating that after patent invalidations, firms do not increase retained earnings relative to lagged total assets. Note, however, that the $t$-value of the estimated coefficient on instrumented invalidation is 1.64 , which is close to the threshold for statistical significance at the $10 \%$ level.

In Column (3), the dependent variable is the ratio of common equity minus retained earnings to total assets. The second-stage regression returns a statistically insignificant coefficient of 0.438 for instrumented invalidation, indicating no significant effect of patent invalidation on the equity (less retained earnings)-to-assets ratio. In Column (4), we define equity issuance as the percentage change in equity less retained earnings. The estimated coefficient of -0.050 is insignificant ( $t$-value of -0.11$)$, implying that firms do not seem to issue 
new equity after a patent invalidation. In Column (5), we divide the change in equity minus retained earnings by lagged assets, and the coefficient on instrumented invalidation is again insignificant ( $t$-value of 1.09). Columns (3) to (5) indicate that equity issuance does not seem to drive the deleveraging after patent invalidations that we document in our main finding.

\section{Conclusion}

This study provides a potential explanation for the incomplete tangibility-leverage relationship (Graham et al., 2015) by documenting the existence of a substantial, positive and causal effect of intangible capital on leverage. We show that a patent invalidation (a proxy for a reduction in a firm's intangible capital) leads to a 14.1 percentage point reduction in leverage over the next year. A battery of robustness tests confirms this finding. We also document heterogeneity in the treatment effect. First, we show that, for firms that explicitly use their intangible assets to obtain debt financing (in the form of patent collateral), intangible capital is a key support for leverage. Second, we document that for firms closer to default and for smaller firms, the decrease in leverage after a patent invalidation is more pronounced. More granular capital structure regressions reveal that the deleveraging triggered by a loss of intangible capital is the result of substantial reductions in short-term debt.

Our findings indicate that intangible capital is a relevant leverage-supporting device. The instrumental variable research design used in this paper permits for this causal interpretation of our findings. The identification strategy follows Galasso and Schankerman (2015) and exploits shocks to firms' intangible capital, which we obtain from hand-collected patent invalidations by the Federal Circuit. The random assignment of judges to cases at this court, combined with heterogeneity in judge leniency, make for a plausible instrument for an exogenous loss of intangible capital at the firm level, thereby mitigating endogeneity concerns. 


\section{References}

Altman, E. Financial ratios, discriminant analysis and the prediction of corporate bankruptcy. Journal of Finance 23.4 (1968): 589-609.

Angrist, J. D., \& Pischke, J. - S. Mostly harmless econometrics: An empiricist's companion (2009). Princeton, NJ: Princeton University Press.

Atanasov, V., \& Black, B. Shock-Based Causal Inference in Corporate Finance and Accounting Research. Critical Finance Review 5.2 (2016): 207-304.

Barth, M. E., Kasznik, R., \& McNichols, M. F. Analyst coverage and intangible assets. Journal of Accounting Research 39.1 (2001): 1-34.

Chava, S., Nanda, V., \& Xiao, S. C. Lending to Innovative Firms. Review of Corporate Finance Studies 6.2 (2017): 234-289.

Chilton, A. S., \& Levy, M. K. Challenging the Randomness of Panel Assignment in the Federal Courts of Appeals. Cornell Law Review 101.1 (2015): 1-56.

Corrado, C. A., \& Hulten, C. R. How Do You Measure a "Technological Revolution"? American Economic Review 100.2 (2010): 99-104.

Dangl, T., \& Zechner, J. Debt maturity and the dynamics of leverage. CFS Working Paper Series 547 (2018).

DeAngelo, H., Gonçalves, A. S., \& Stulz, R. M. Corporate Deleveraging and Financial Flexibility. Review of Financial Studies 31.8 (2018): 3122-3174.

Dunner, D. R., Jakes, J. M., \& Karceski, J. D. Statistical Look at the Federal Circuit's Patent Decisions: 1982-1994. Federal Circuit Bar Journal 5 (1995): 151-179.

Eisfeldt, A. L., \& Rampini, A. A. Leasing, ability to repossess, and debt capacity. Review of Financial Studies 22.4 (2009): 1621-1657. 
Farre-Mensa, J., Hegde, D., \& Ljungqvist, A. What is a Patent Worth? Evidence from the U.S. Patent 'Lottery'. Journal of Finance (forthcoming).

Frank, M. Z., \& Goyal, V. K. Capital structure decisions: which factors are reliably important? Financial Management 38.1 (2009): 1-37.

Galasso, A., \& Schankerman, M. Patents and cumulative innovation: Causal evidence from the courts. Quarterly Journal of Economics 130.1 (2015): 317-369.

Graham, J. R., \& Harvey, C. How Do CFOs Make Capital Budgeting and Capital Structure Decisions? Journal of Applied Corporate Finance 15 (2002): 8-23.

Graham, J. R., \& Leary, M. T. A Review of Empirical Capital Structure Research and Directions for the Future. Annual Review of Financial Economics 3 (2011): 309-345.

Graham, J. R., Leary, M. T. \& Roberts, M. R. A century of capital structure: The leveraging of corporate America. Journal of Financial Economics 118.3 (2015): 658-683.

Hall, M. Randomness Reconsidered: Modeling the Random Judicial Assignment in the U.S. Courts of Appeals. Journal of Empirical Legal Studies 7.3 (2010): 574-589.

Hall, B. B., Jaffe, A. B., \& Trajtenberg, M. The NBER Patent Citation Data File: Lessons, Insights and Methodological Tools. NBER Working Paper No. 8498 (2001).

Harris, M., \& Raviv, A. The Theory of Capital Structure. Journal of Finance 46.1 (1991): $297-$ 355.

Heider, F., \& Ljungqvist, A. As certain as debt and taxes: Estimating the tax sensitivity of leverage from state tax changes. Journal of Financial Economics 118.3 (2015): 684-712.

Hochberg, Y. V., Serrano, C. J., \& Ziedonis, R. H. Patent collateral, investor commitment, and the market for venture lending Journal of Financial Economics 130.1 (2018): 74-94. 
Imbens, G. W., \& Angrist, J. D. Identification and Estimation of Local Average Treatment Effects. Econometrica 62.2 (1994): 467-475.

Kleibergen, F., \& Paap, R. Generalized reduced rank tests using the singular value decomposition. Journal of Econometrics 133.1 (2006): 97-126.

Kogan, L., Papanikolaou, D., Seru, A., \& Stoffman, N. Technological Innovation, Resource Allocation and Growth. Quarterly Journal of Economics 132.2 (2017): 665-712.

Larkin, Y. Brand perception, cash flow stability, and financial policy. Journal of Financial Economics 110.1 (2013): 232-253.

Leary, M. T., \& Roberts, M. R. Do peer firms affect corporate financial policy? Journal of Finance 69.1 (2014): 139-178.

Lemmon, M. L., Roberts, M. R., \& Zender, J. F. Back to the beginning: persistence and the cross-section of corporate capital structure. Journal of Finance 63.4 (2008): 1575-1608.

Lemmon, M. L., \& Zender, J. F. Debt Capacity and Tests of Capital Structure Theories. Journal of Financial and Quantitative Analysis 45.5 (2010): 1161-1187.

Lim, S. C., Macias, A. J., \& Moeller, T. Identifiable Intangible Assets and Capital Structure. Working Paper (2018).

Long, M. S., \& Malitz, I. B. Investment Patterns and Financial Leverage, in Friedman, B., ed. Corporate Capital Structures in the United States (1985). Chicago, IL: University of Chicago Press.

Loumioti, M. The Use of Intangible Assets as Loan Collateral. Working Paper (2013).

Mann, W. Creditor rights and innovation: Evidence from patent collateral. Journal of Financial Economics 130.1 (2018): 25-47.

Myers, S. C. The capital structure puzzle. Journal of Finance 39.3 (1984): 574-592. 
Rajan, R. G., \& Zingales, L. What Do We Know about Capital Structure? Some Evidence from International Data. Journal of Finance 50.5 (1995): 1421-1460.

Rampini, A. A., \& Viswanathan, S. Collateral and Capital Structure. Journal of Financial Economics 109.2 (2013): 466-492.

Rauh, J. D., \& Sufi, A. Explaining Corporate Capital Structure: Product Markets, Leases, and Asset Similarity. Review of Finance 16.1 (2012): 115-155.

Roberts, M. R., \& Whited, T. M. Endogeneity in empirical corporate finance, in Constantinides, G., Harris, M., \& Stulz, R., eds. Handbook of the Economics of Finance Volume 2 (2013). Amsterdam, Holland: Elsevier.

Serfling, M. Firing costs and capital structure decisions. Journal of Finance 71.5 (2016): 22392286.

Shleifer, A., \& Vishny, R. M. Liquidation values and debt capacity: A market equilibrium approach. Journal of Finance 47.4 (1992): 1343-1366.

Staiger, D., \& Stock, J. H. Instrumental Variables Regression with Weak Instruments. Econometrica 65.3 (1997): 557-586.

Stock, J. H., \& Yogo, M. Testing for weak instruments in linear IV regression. Identification and inference for econometric models: Essays in honor of Thomas Rothenberg (2005). New York, NY: Cambridge University Press.

Titman, S., \& Wessels, R. The Determinants of Capital Structure Choice. Journal of Finance 42.1 (1988): 1-19.

Wall Street Journal. Accounting's 21st Century Challenge: How to Value Intangible Assets. CFO Journal, March 21, 2016. 
Wooldridge, J. M. Econometric analysis of cross section and panel data (2010). Cambridge, MA: MIT Press.

Zou, H., \& Adams, M. B. Debt Capacity, Cost of Debt, and Corporate Insurance. Journal of Financial and Quantitative Analysis 43.2 (2008): 433-466. 


\section{Appendix A. Judges' Individual Patent Invalidation Propensities.}

This table summarizes the individual patent invalidation propensities for the 25 Federal Circuit judges most frequently present in our sample. A judge's individual patent invalidation propensity is computed per patent invalidity decision as the ratio of all of her votes in favor of patent invalidation divided by all of her votes on patent validity, over the judge's entire Federal Circuit career and excluding the patent invalidity decision at hand. Following Galasso and Schankerman (2015), we record a patent invalidity decision as a patent invalidation if the three-judge panel invalidates at least one claim of a focal patent.

\begin{tabular}{|c|c|c|}
\hline Judge & $\begin{array}{c}\text { Number of Patent } \\
\text { Invalidity Decisions }\end{array}$ & $\begin{array}{c}\text { Judge's Individual Patent Invalidation Propensity } \\
\text { (\% of votes in favor of patent invalidity) }\end{array}$ \\
\hline Newman & 142 & $18 \%$ \\
\hline Bryson & 134 & $57 \%$ \\
\hline Rader & 131 & $39 \%$ \\
\hline Lourie & 114 & $47 \%$ \\
\hline Prost & 111 & $54 \%$ \\
\hline Dyk & 104 & $61 \%$ \\
\hline Mayer & 99 & $49 \%$ \\
\hline Gajarsa & 91 & $48 \%$ \\
\hline Michel & 83 & $40 \%$ \\
\hline Linn & 72 & $49 \%$ \\
\hline Clevenger & 67 & $46 \%$ \\
\hline Schall & 64 & $45 \%$ \\
\hline Archer & 50 & $36 \%$ \\
\hline Plager & 49 & $51 \%$ \\
\hline Moore & 48 & $63 \%$ \\
\hline Wallach & 36 & $22 \%$ \\
\hline Markey & 36 & $50 \%$ \\
\hline Rich & 31 & $26 \%$ \\
\hline Friedman & 31 & $42 \%$ \\
\hline O'Malley & 29 & $48 \%$ \\
\hline Davis & 25 & $48 \%$ \\
\hline Reyna & 21 & $38 \%$ \\
\hline Smith & 21 & $24 \%$ \\
\hline Nies & 19 & $32 \%$ \\
\hline Cowen & 17 & $41 \%$ \\
\hline
\end{tabular}


Appendix B. Variable Definitions.

\begin{tabular}{|c|c|}
\hline Variable & Definition (Compustat variable names) \\
\hline \multicolumn{2}{|l|}{ Patent invalidity decision variables } \\
\hline Invalidated & $\begin{array}{l}\text { equals one if the Federal Circuit invalidates at least one } \\
\text { patent claim, and zero otherwise }\end{array}$ \\
\hline Judges' invalidation propensity (JIP) & $\begin{array}{l}\text { predicted propensity of the judge panel randomly assigned to } \\
\text { a court case at the Federal Circuit to invalidate a patent, } \\
\text { based on judges' historical invalidation votes observed in } \\
\text { other patent validity cases }\end{array}$ \\
\hline \multicolumn{2}{|l|}{ Dependent variables } \\
\hline Book leverage & $(d l t t+d l c) / a t$ \\
\hline Market leverage & $(d l t t+d l c) /\left(p r c c f^{*} c s h p r i+d l t t+d l c+p s t k l-t x d i t c\right)$ \\
\hline Lease-adjusted book leverage & $(d l t t+d l c+x r e n t * 10) /(a t+x r e n t * 10)$ \\
\hline Net book leverage & $(d l t t+d l c-c h e) / a t$ \\
\hline Net debt issuer & equals one if $(d l t t+d l c-(l . d l t t+l . d l c)) / l . a t$ exceeds 0.01 \\
\hline Short-term leverage & $d l c / a t$ \\
\hline$\Delta$ Short-term debt $(\%)$ & $(d l c-l . d l c) / l . d l c$ \\
\hline $\begin{array}{l}\Delta \text { Short-term debt }(\% \text { of lagged } \\
\text { assets })\end{array}$ & $(d l c-l . d l c) / l . a t$ \\
\hline Long-term leverage & dltt / at \\
\hline$\Delta$ Long-term debt $(\%)$ & $(d l t t-l . d l t t) / l . d l t t$ \\
\hline $\begin{array}{l}\Delta \text { Long-term debt }(\% \text { of lagged } \\
\text { assets) }\end{array}$ & $(d l t t-l . d l t t) / l . a t$ \\
\hline Retained earnings / assets & re / at \\
\hline $\begin{array}{l}\Delta \text { Retained earnings (\% of lagged } \\
\text { assets) }\end{array}$ & $($ re - l.re $) /$ l.at \\
\hline (Equity - retained earnings) / assets & $(c e q-r e) / a t$ \\
\hline$\Delta$ (Equity - retained earnings) $(\%)$ & $((c e q-r e)-($ l.ceq - l.re $)) /($ l.ceq - l.re $)$ \\
\hline $\begin{array}{l}\Delta \text { (Equity - retained earnings) (\% of } \\
\text { lagged assets) }\end{array}$ & $((c e q-r e)-(l . c e q-$ l.re $)) /$ l.at \\
\hline \multicolumn{2}{|l|}{ Further variables } \\
\hline Citations received & $\begin{array}{l}\text { Number of times a patent is cited according to data from the } \\
\text { NBER Patent Data Project, adjusted for truncation using the } \\
\text { adjustment factor by Hall et al. (2001) }\end{array}$ \\
\hline Number of claims & $\begin{array}{l}\text { Number of patent claims, according to data from the NBER } \\
\text { Patent Data Project }\end{array}$ \\
\hline Citations received per claim & Citations received / Number of claims \\
\hline Patent value in million nominal USD & $\begin{array}{l}\text { Kogan et al. (2017) patent value, according to data obtained } \\
\text { from N. Stoffman's website }\end{array}$ \\
\hline Patent value in million 2017 USD & $\begin{array}{l}\text { Patent value in million nominal USD, adjusted for inflation } \\
\text { using the GDP Implicit Price Deflator published by the } \\
\text { Federal Reserve Bank of St. Louis (FRED) }\end{array}$ \\
\hline Size & $\log ($ sale $)$ \\
\hline Market-to-book & $\left(p r c c \_f^{*} c s h p r i+d l t t+d l c+p s t k l-t x d i t c\right) / a t$ \\
\hline Profitability & oibdp / at \\
\hline Tangibility & ppent / at \\
\hline Patent is collateral & $\begin{array}{l}\text { equals one if the patent is assigned as collateral in a loan } \\
\text { agreement at the time of the invalidity decision (data from } \\
\text { USPTO assignment database), and zero otherwise }\end{array}$ \\
\hline Modified Altman Z-Score & $(3.3 * p i+$ sale $+1.4 * r e+1.2 *(a c t-l c t)) / a t$ \\
\hline
\end{tabular}




\section{Table 1. How Do Sample Patents Compare to the Average US Patent?}

This table compares patent value measures between the universe of US patents and the patents in our sample. Panel A uses patent citation data for patents granted between 1976 and 2006 from the NBER Patent Data Project. Citations received is adjusted for truncation using the adjustment factor by Hall et al. (2001). Panel B uses the measure of economic patent value developed by Kogan et al. (2017), which we obtain from N. Stoffman's website. In the last row, we adjust the nominal patent value measure (variable $x i$ in the Kogan et al. (2017) dataset) for inflation, using the GDP Implicit Price Deflator published by the Federal Reserve Bank of St. Louis (FRED). ${ }^{* * *}$, ${ }^{* *}$, and ${ }^{*}$ denote statistical difference of the means, based on two-tailed $p$-values, at the $1 \%, 5 \%$, and $10 \%$ significance level, respectively. All variables are defined in Appendix B.

\begin{tabular}{|c|c|c|c|c|c|}
\hline & \multirow[b]{2}{*}{$\begin{array}{l}\text { US patents, } \\
\text { excl. sample }\end{array}$} & \multirow[b]{2}{*}{$\begin{array}{l}\text { Sample } \\
\text { patents }\end{array}$} & \multirow[b]{2}{*}{$\begin{array}{c}\text { Mean } \\
\text { difference }\end{array}$} & \multicolumn{2}{|c|}{$\begin{array}{c}\text { Galasso and Schankerman } \\
(2015, \text { Table II })\end{array}$} \\
\hline & & & & $\begin{array}{c}\text { All patents } \\
\text { granted not } \\
\text { litigated }\end{array}$ & $\begin{array}{l}\text { Litigated at } \\
\text { lower courts } \\
\text { and appealed }\end{array}$ \\
\hline \multicolumn{6}{|l|}{ Panel A: Scientific Patent Value } \\
\hline Number of patents & $3,208,645$ & 401 & & $1,808,770$ & 877 \\
\hline Citations received & 11.8 & 49.8 & $38^{* * *}$ & & \\
\hline Number of claims & 14.4 & 23.8 & $9.4^{* * *}$ & 12.5 & 19.0 \\
\hline Citations received per claim & 1.4 & 4.1 & $2.7^{* * *}$ & 1.0 & 2.3 \\
\hline \multicolumn{6}{|l|}{ Panel B: Economic Patent Value } \\
\hline Number of patents & $1,790,342$ & 256 & & & \\
\hline Patent value in million nominal USD & 10.4 & 17.6 & $7.3^{* * *}$ & & \\
\hline Patent value in million 2017 USD & 22.4 & 28.6 & $6.2^{*}$ & & \\
\hline
\end{tabular}


Table 2. Summary Statistics.

This table reports summary statistics of patent invalidity decision variables (Panel A), dependent variables (Panel B) and further variables used in this paper (Panel C). To reduce the effects of outliers, financial ratios are winsorized at the $1 \%$ and $99 \%$ level. We obtain the invalidity decision variables from a hand-collected set of 579 patent invalidity court decisions issued by the Federal Circuit between 1983 and 2014. Following Galasso and Schankerman (2015), Invalidated equals one if the Federal Circuit invalidates at least one patent claim. Judges' invalidation propensity $(J I P)$ is the predicted probability that the three-judge panel randomly assigned to the invalidity decision invalidates the focal patent. All variables are defined in Appendix B.

\begin{tabular}{lcccc}
\hline & $\mathrm{n}$ & mean & median & s. d. \\
\hline Panel A: Patent invalidity decision variables & & & & \\
Invalidated & 579 & 0.45 & 0.00 & 0.50 \\
Judges' invalidation propensity (JIP) & 579 & 0.42 & 0.43 & 0.11 \\
\hline Panel B: Dependent variables & & & & \\
Book leverage & 579 & 0.21 & 0.20 & 0.14 \\
Market leverage & 554 & 0.16 & 0.13 & 0.14 \\
Lease-adjusted book leverage & 511 & 0.28 & 0.28 & 0.13 \\
Net book leverage & 579 & 0.04 & 0.08 & 0.25 \\
Net debt issuer & 579 & 0.39 & 0.00 & 0.49 \\
Short-term leverage & 579 & 0.04 & 0.03 & 0.05 \\
$\Delta$ Short-term debt (\%) & 501 & 2.33 & 0.04 & 10.07 \\
$\Delta$ Short-term debt (\% of lagged assets) & 579 & 0.00 & 0.00 & 0.05 \\
Long-term leverage & 579 & 0.16 & 0.16 & 0.12 \\
$\Delta$ Long-term debt (\%) & 502 & 0.23 & 0.00 & 0.82 \\
$\Delta$ Long-term debt (\% of lagged assets) & 579 & 0.02 & 0.00 & 0.11 \\
Retained earnings / assets & 578 & -0.02 & 0.31 & 1.38 \\
$\Delta$ Retained earnings (\% of lagged assets) & 578 & 0.01 & 0.03 & 0.14 \\
(Equity - retained earnings) / assets & 578 & 0.49 & 0.11 & 1.36 \\
$\Delta$ (Equity - retained earnings) (\%) & 578 & 0.10 & 0.03 & 0.86 \\
$\Delta$ (Equity - retained earnings) (\% of lagged assets) & 578 & 0.05 & 0.00 & 0.23 \\
\hline Panel C: Further variables & & & & \\
Size & 579 & 8.33 & 8.93 & 2.48 \\
Market-to-book & 579 & 2.03 & 1.55 & 1.46 \\
Profitability & 579 & 0.15 & 0.15 & 0.12 \\
Tangibility & 579 & 0.23 & 0.20 & 0.16 \\
Patent is collateral & 579 & 0.08 & 0.00 & 0.27 \\
Modified Altman Z-Score & 569 & 1.27 & 1.87 & 2.75 \\
\hline
\end{tabular}


Table 3. First Stage: Predicting Patent Invalidation from Judges' Voting Behavior.

This table summarizes the results from OLS first-stage regressions of the patent invalidity decision (Invalidated) on two instruments of patent invalidation. Judges' invalidation propensity $(J I P)$ is the predicted probability that the three-judge panel randomly assigned to the patent invalidity decision invalidates the focal patent. Predicted invalidation is obtained from a probit regression of the patent invalidation dummy (Invalidated) on JIP and control variables. The estimate in Column (3) represents the first-stage estimate upon which the second-stage estimate of Column (4) in Panel A of Table 4 is based. The reported IV test statistic is the Kleibergen-Paap (2006) Wald rk Fstatistic for weak identification. All control variables are measured at the end of the fiscal year before the patent invalidity decision. Heteroskedasticity-robust standard errors clustered at the firm-level are reported in parentheses below the coefficients. All financial variables are winsorized at $1 \%$ and $99 \%$. ***, **, and * denote statistical significance at $1 \%, 5 \%$, and 10\%, respectively. All variables are defined in Appendix B.

\begin{tabular}{lccc}
\hline & \multicolumn{3}{c}{ Dependent variable: Invalidated } \\
\cline { 2 - 4 } & $(1)$ & $(2)$ & $(3)$ \\
\hline Instruments for patent invalidation & & & \\
Judges' invalidation propensity $(J I P)$ & $0.990^{* * *}$ & & \\
& $(0.300)$ & $1.088^{* * *}$ & $1.116^{* * *}$ \\
Predicted invalidation & & $(0.283)$ & $(0.297)$ \\
& & \\
Control variables & & -0.017 \\
Book leverage & & $(0.218)$ \\
& & -0.001 \\
Size & & & $(0.016)$ \\
& & -0.003 \\
Market-to-book & & $(0.027)$ \\
& & & 0.010 \\
Profitability & & & $(0.320)$ \\
& & -0.009 \\
Tangibility & & $(0.257)$ \\
Year fixed effects & Yes & Yes & Yes \\
FF 48 industry fixed effects & Yes & Yes & Yes \\
IV test & 10.90 & 14.82 & 14.14 \\
Number of observations & 579 & 579 & 579 \\
\hline
\end{tabular}


Table 4. Second Stage: Effect of Intangible Capital on Leverage.

Panel A summarizes the results from OLS (Columns (1) and (2)) and 2SLS (Columns (3) and (4)) regressions of book leverage on patent invalidation and control variables. In Columns (1) and (2), the patent invalidation dummy (Invalidated) is used as an explanatory variable. In Columns (3) and (4), Invalidated is instrumented by the predicted patent invalidation obtained from a probit regression of Invalidated on JIP and control variables. The dependent variable is measured at the end of the fiscal year after the patent invalidity decision. All control variables are measured at the end of the fiscal year before the patent invalidity decision. In all regressions, heteroskedasticityrobust standard errors clustered at the firm-level are reported in parentheses below the coefficients. All financial variables are winsorized at $1 \%$ and $99 \%$. ***, **, and $*$ denote statistical significance at $1 \%, 5 \%$, and $10 \%$, respectively. All variables are defined in Appendix B. Panel B summarizes the results from 2SLS regressions of alternative leverage measures on patent invalidation and control variables. Panel $\mathrm{C}$ summarizes the results from 2SLS regressions of book leverage on patent invalidation and control variables, under alternative empirical specifications. In Column (1), control variables are measured at the end of the fiscal year of the patent invalidity decision. In Column (2), financial variables are winsorized at 5\% and 95\%. In Column (3), the dependent variable is the one-year change in the book leverage ratio, computed as the first difference from year $t=0$ to year $t+1$. The control variables are the first differences measured between year $t-2$ and year $t-1$. In Column (4), we collapse the sample from the firm-invalidity decision level to the firm-case level. We define case-level JIP as the mean JIP per case and set the invalidation dummy to one if at least one patent is invalidated during the case.

\begin{tabular}{|c|c|c|c|c|}
\hline \multicolumn{5}{|l|}{ Panel A: Book Leverage } \\
\hline \multirow[b]{2}{*}{ Estimation method: } & $(1)$ & $(2)$ & (3) & $(4)$ \\
\hline & OLS & OLS & 2SLS & 2SLS \\
\hline \multirow[t]{2}{*}{ Invalidation } & 0.005 & 0.003 & $-0.212^{* * *}$ & $-0.141^{* *}$ \\
\hline & $(0.017)$ & $(0.009)$ & $(0.082)$ & $(0.060)$ \\
\hline \multirow[t]{2}{*}{ Book leverage } & & $0.705^{* * *}$ & & $0.718^{* * *}$ \\
\hline & & $(0.059)$ & & $(0.064)$ \\
\hline \multirow[t]{2}{*}{ Size } & & -0.005 & & -0.004 \\
\hline & & $(0.005)$ & & $(0.006)$ \\
\hline \multirow[t]{2}{*}{ Market-to-book } & & -0.003 & & 0.003 \\
\hline & & $(0.006)$ & & $(0.007)$ \\
\hline \multirow[t]{2}{*}{ Profitability } & & 0.053 & & 0.037 \\
\hline & & $(0.082)$ & & $(0.099)$ \\
\hline \multirow[t]{2}{*}{ Tangibility } & & -0.059 & & -0.103 \\
\hline & & $(0.068)$ & & $(0.078)$ \\
\hline Year fixed effects & Yes & Yes & Yes & Yes \\
\hline FF 48 industry fixed effects & Yes & Yes & Yes & Yes \\
\hline Number of observations & 579 & 579 & 579 & 579 \\
\hline \multicolumn{5}{|c|}{ Panel B: Alternative Leverage Measures } \\
\hline & \multicolumn{4}{|c|}{ Dependent Variable: } \\
\hline & (1) & $(2)$ & $(3)$ & $(4)$ \\
\hline & $\begin{array}{l}\text { Market } \\
\text { leverage }\end{array}$ & $\begin{array}{l}\text { Lease-adjusted } \\
\text { book leverage }\end{array}$ & $\begin{array}{l}\text { Net book } \\
\text { leverage }\end{array}$ & Net debt issuer \\
\hline \multirow[t]{2}{*}{ Invalidation } & $-0.132^{* *}$ & $-0.161^{* *}$ & $-0.140^{*}$ & $-0.587^{* *}$ \\
\hline & $(0.057)$ & $(0.079)$ & $(0.079)$ & $(0.262)$ \\
\hline \multirow[t]{2}{*}{ Book leverage } & $0.629^{* * *}$ & $0.748^{* * *}$ & $0.667^{* * *}$ & $0.128^{*}$ \\
\hline & $(0.069)$ & $(0.066)$ & $(0.055)$ & $(0.071)$ \\
\hline \multirow[t]{2}{*}{ Size } & -0.001 & -0.002 & $0.013^{*}$ & 0.019 \\
\hline & $(0.005)$ & $(0.005)$ & $(0.007)$ & $(0.020)$ \\
\hline \multirow[t]{2}{*}{ Market-to-book } & 0.000 & 0.001 & -0.005 & $0.060^{* *}$ \\
\hline & $(0.008)$ & $(0.008)$ & $(0.011)$ & $(0.030)$ \\
\hline \multirow[t]{2}{*}{ Profitability } & -0.012 & -0.009 & -0.085 & -0.162 \\
\hline & $(0.087)$ & $(0.100)$ & $(0.131)$ & $(0.406)$ \\
\hline \multirow[t]{2}{*}{ Tangibility } & -0.026 & -0.103 & -0.040 & -0.052 \\
\hline & $(0.060)$ & $(0.083)$ & $(0.090)$ & $(0.290)$ \\
\hline Year fixed effects & Yes & Yes & Yes & Yes \\
\hline FF 48 industry fixed effects & Yes & Yes & Yes & Yes \\
\hline Number of observations & 554 & 503 & 579 & 577 \\
\hline
\end{tabular}


Table 4. Second Stage: Effect of Intangible Capital on Leverage (continued).

\begin{tabular}{|c|c|c|c|c|}
\hline \multicolumn{5}{|c|}{ Panel C: Alternative Empirical Specifications } \\
\hline \multirow[b]{3}{*}{ Estimation method } & \multicolumn{4}{|c|}{ Dependent Variable: Book Leverage } \\
\hline & $(1)$ & $(2)$ & $(3)$ & $(4)$ \\
\hline & $\begin{array}{c}\text { Control } \\
\text { variables at } t=0\end{array}$ & $\begin{array}{c}\text { Financials } \\
\text { winsorized at } \\
5 \% \text { and } 95 \%\end{array}$ & $\begin{array}{l}\text { Change on } \\
\text { changes } \\
\text { regression }\end{array}$ & $\begin{array}{c}\text { Unit of } \\
\text { observation: } \\
\text { firm-case }\end{array}$ \\
\hline \multirow[t]{2}{*}{ Invalidation } & $-0.118^{* * *}$ & $-0.116^{* *}$ & $-0.069^{* *}$ & $-0.099^{* *}$ \\
\hline & $(0.044)$ & $(0.053)$ & $(0.031)$ & $(0.041)$ \\
\hline \multirow[t]{2}{*}{ Book leverage } & $0.499^{* * *}$ & $0.761^{* * *}$ & $-0.293^{*}$ & $0.711^{* * *}$ \\
\hline & $(0.134)$ & $(0.053)$ & $(0.153)$ & $(0.065)$ \\
\hline \multirow[t]{2}{*}{ Size } & 0.002 & -0.004 & $0.046^{* * *}$ & -0.003 \\
\hline & $(0.006)$ & $(0.004)$ & $(0.014)$ & $(0.005)$ \\
\hline \multirow[t]{2}{*}{ Market-to-book } & -0.005 & 0.004 & $0.011^{* *}$ & -0.004 \\
\hline & $(0.003)$ & $(0.008)$ & $(0.005)$ & $(0.006)$ \\
\hline \multirow[t]{2}{*}{ Profitability } & -0.019 & 0.046 & $-0.225^{* *}$ & 0.032 \\
\hline & $(0.060)$ & $(0.104)$ & $(0.091)$ & $(0.083)$ \\
\hline \multirow[t]{2}{*}{ Tangibility } & -0.017 & -0.089 & -0.021 & -0.034 \\
\hline & $(0.066)$ & $(0.069)$ & $(0.130)$ & $(0.066)$ \\
\hline Year fixed effects & Yes & Yes & Yes & Yes \\
\hline FF 48 industry fixed effects & Yes & Yes & Yes & Yes \\
\hline Number of observations & 563 & 579 & 551 & 372 \\
\hline
\end{tabular}




\section{Table 5. Second Stage with Interactions: Heterogeneous Effects of Intangible Capital on Leverage.}

This table summarizes the results from interacted 2SLS regressions of book leverage on patent invalidation and control variables. We estimate the interacted 2SLS regressions as follows: We first compute the binary interaction terms (Patent is Collateral, Low Z-Score and Small Firm), which take on values of one or zero. For each specification, we then multiply the endogenous independent variable, Invalidated, with the interaction dummy. We then estimate a probit regression of Invalidated on JIP, the interaction dummy and the control variables. We use this estimate to predict instrumented patent invalidation, the primary instrumental variable. We then multiply the instrumented patent invalidation with the interaction dummy to obtain a second instrument. Finally, we run a 2SLS regression, where two endogenous variables, Invalidated and Invalidated multiplied by the interaction dummy, are instrumented by instrumented patent invalidation and instrumented patent invalidation multiplied by the interaction dummy. The dependent variable is measured at the end of the fiscal year following the patent invalidity decision. All control variables are measured at the end of the fiscal year before the patent invalidity decision. Heteroskedasticity-robust standard errors clustered at the firm-level are reported in parentheses below the coefficients. All financial variables are winsorized at $1 \%$ and $99 \%$. ***, **, and * denote statistical significance at $1 \%, 5 \%$, and $10 \%$, respectively. All variables are defined in Appendix B.

\begin{tabular}{lccc}
\hline & \multicolumn{2}{c}{ Dependent } & \multicolumn{2}{c}{ variable: Book leverage } \\
\cline { 2 - 4 } & $(1)$ & -0.062 & $(3)$ \\
\hline Invalidation & $-0.106^{*}$ & $(0.058)$ & $(0.052)$ \\
Invalidation $\times$ Patent is Collateral & $-0.284^{*}$ & & \\
Patent is Collateral & $(0.167)$ & & \\
& $0.114^{*}$ & & \\
Invalidation $\times$ Low Z-Score & $(0.069)$ & & \\
& & $-0.151^{* *}$ & \\
Low Z-Score & & $(0.073)$ & $-0.148^{*}$ \\
& & 0.057 & $(0.078)$ \\
Invalidation $\times$ Small Firm & & $(0.038)$ & $0.077^{*}$ \\
Small Firm & & & $(0.042)$ \\
Book leverage & & & $0.706^{* * *}$ \\
Size & & & $(0.071)$ \\
Market-to-book & & -0.002 \\
Profitability & $(0.063)$ & $(0.072)$ & $(0.008)$ \\
Tangibility & -0.005 & -0.005 & 0.005 \\
Year fixed effects & $(0.005)$ & $(0.006)$ & $(0.008)$ \\
FF 48 industry fixed effects & 0.003 & 0.001 & -0.002 \\
Number of observations & $(0.007)$ & $(0.008)$ & $(0.113)$ \\
& 0.045 & 0.019 & -0.074 \\
& $(0.092)$ & $(0.105)$ & $(0.081)$ \\
& -0.091 & -0.121 & Yes \\
& $(0.076)$ & $(0.084)$ & 579 \\
\hline
\end{tabular}


Table 6. Second Stage: How Does the Deleveraging After Patent Invalidation

\section{Materialize?}

This table summarizes the results from 2SLS regressions of leverage indicators related to the debt channel (Panel A) and to the equity channel (Panel B), respectively, on patent invalidation and control variables. As in Column (4) of Panel A in Table 4, the patent invalidation dummy (Invalidated) is instrumented by the predicted patent invalidation obtained from a probit regression of Invalidated on JIP and control variables. Each dependent variable is measured at the end of the fiscal year following the patent invalidity decision. All control variables are measured at the end of the fiscal year before the patent invalidity decision. Heteroskedasticity-robust standard errors clustered at the firm-level are reported in parentheses below the coefficients. All financial variables are winsorized at $1 \%$ and $99 \%$. ***, $* *$, and $*$ denote statistical significance at $1 \%, 5 \%$, and $10 \%$, respectively. All variables are defined in Appendix B.

\begin{tabular}{|c|c|c|c|c|c|}
\hline \multirow[t]{4}{*}{ Panel A: Debt Channel } & \multicolumn{5}{|c|}{ Dependent Variable: } \\
\hline & $(1)$ & $(2)$ & $(3)$ & (4) & $(5)$ \\
\hline & Short-Term & $\Delta$ Short- & $\Delta$ Short- & Long-Term & $\Delta$ Long-Term \\
\hline & Leverage & $\begin{array}{l}\text { Term Debt } \\
(\%)\end{array}$ & $\begin{array}{l}\text { Term Debt } \\
\text { (\% of lagged } \\
\text { assets })\end{array}$ & Leverage & $\begin{array}{c}\text { Debt } \\
(\%)\end{array}$ \\
\hline \multirow[t]{2}{*}{ Invalidation } & $-0.052^{* *}$ & $-7.193^{* *}$ & $-0.053^{* *}$ & $-0.090^{*}$ & -0.126 \\
\hline & $(0.025)$ & $(3.641)$ & $(0.026)$ & $(0.052)$ & $(0.412)$ \\
\hline \multirow[t]{2}{*}{ Lagged dep. var. } & $0.381^{* * *}$ & -0.027 & $-0.157^{* * *}$ & $0.648^{* * *}$ & 0.030 \\
\hline & $(0.083)$ & $(0.095)$ & $(0.054)$ & $(0.068)$ & $(0.048)$ \\
\hline \multirow[t]{2}{*}{ Size } & 0.001 & -0.015 & -0.000 & -0.002 & -0.003 \\
\hline & $(0.002)$ & $(0.408)$ & $(0.002)$ & $(0.005)$ & $(0.033)$ \\
\hline \multirow[t]{2}{*}{ Market-to-book } & 0.004 & 0.782 & $0.005^{*}$ & -0.005 & 0.080 \\
\hline & $(0.003)$ & $(0.726)$ & $(0.003)$ & $(0.007)$ & $(0.061)$ \\
\hline \multirow[t]{2}{*}{ Profitability } & $-0.070^{*}$ & -3.186 & -0.008 & 0.123 & -0.243 \\
\hline & $(0.039)$ & $(11.287)$ & $(0.033)$ & $(0.095)$ & $(0.689)$ \\
\hline \multirow[t]{2}{*}{ Tangibility } & -0.001 & $-12.587^{* *}$ & -0.015 & -0.072 & -0.596 \\
\hline & $(0.025)$ & $(5.337)$ & $(0.025)$ & $(0.071)$ & $(0.404)$ \\
\hline Year fixed effects & Yes & Yes & Yes & Yes & Yes \\
\hline FF 48 industry fixed effects & Yes & Yes & Yes & Yes & Yes \\
\hline Number of observations & 579 & 486 & 578 & 579 & 491 \\
\hline \multirow[t]{6}{*}{ Panel B: Equity Channel } & \multicolumn{5}{|c|}{ Dependent Variable: } \\
\hline & (1) & $(2)$ & $(3)$ & $(4)$ & $(5)$ \\
\hline & Retained & $\Delta$ Retained & (Equity - & $\Delta$ (Equity - & $\Delta$ (Equity - \\
\hline & Earnings & Earnings & RE) & RE) & RE) \\
\hline & 1 & (\% of lagged & 1 & $(\%)$ & (\% of lagged \\
\hline & Assets & assets) & Assets & & assets) \\
\hline \multirow[t]{2}{*}{ Invalidation } & -0.207 & 0.111 & 0.438 & -0.050 & 0.111 \\
\hline & $(0.395)$ & $(0.068)$ & $(0.379)$ & $(0.467)$ & $(0.102)$ \\
\hline \multirow[t]{2}{*}{ Lagged dep. var. } & $0.717^{* * *}$ & $0.203^{*}$ & $0.680^{* * *}$ & -0.023 & 0.082 \\
\hline & $(0.162)$ & $(0.123)$ & $(0.162)$ & $(0.027)$ & $(0.115)$ \\
\hline \multirow[t]{2}{*}{ Size } & 0.060 & 0.007 & -0.073 & -0.061 & $-0.023^{* *}$ \\
\hline & $(0.047)$ & $(0.006)$ & $(0.047)$ & $(0.040)$ & $(0.010)$ \\
\hline \multirow[t]{2}{*}{ Market-to-book } & 0.007 & -0.006 & 0.003 & -0.058 & 0.004 \\
\hline & $(0.058)$ & $(0.008)$ & $(0.064)$ & $(0.060)$ & $(0.016)$ \\
\hline \multirow[t]{2}{*}{ Profitability } & 2.144 & $0.226^{*}$ & $-2.482^{*}$ & 0.440 & $-0.719^{* * *}$ \\
\hline & $(1.475)$ & $(0.119)$ & $(1.466)$ & $(0.624)$ & $(0.230)$ \\
\hline \multirow[t]{2}{*}{ Tangibility } & 0.018 & 0.085 & 0.154 & -0.263 & 0.122 \\
\hline & $(0.386)$ & $(0.059)$ & $(0.385)$ & $(0.334)$ & $(0.092)$ \\
\hline Year fixed effects & Yes & Yes & Yes & Yes & Yes \\
\hline FF 48 industry fixed effects & Yes & Yes & Yes & Yes & Yes \\
\hline Number of observations & 578 & 575 & 578 & 575 & 575 \\
\hline
\end{tabular}

